\title{
Solar Distillation System Based on Multiple-Effect Diffusion Type Still
}

\author{
Bin-Juine Huang ${ }^{* 1}$, Tze-Ling Chong ${ }^{1}$,Hsien-Shun Chang ${ }^{1}$, \\ Po-Hsien $\mathrm{Wu}^{1}$, Yeong-Chuan Kao \\ ${ }^{1}$ Department of Mechanical Engineering \\ National Taiwan University, Taipei, Taiwan \\ e-mail: bjhuang@ seed.net.tw \\ ${ }^{2}$ Department of Physics \\ National Taiwan University, Taipei, Taiwan
}

Cite as: Huang, B.J., Chong, T.L., Chang H.S., Wu, P.H., Kao, Y.C., Solar Distillation System Based on Multiple-Effect Diffusion Type Still, J. sustain. dev. energy water environ. syst., 2(1), pp 41-50, 2014, DOI: http://dx.doi.org/10.13044/j.sdewes.2014.02.0004

\begin{abstract}
The present study intends to develop a high-performance solar-assisted desalination system (SADS) using multi-effect diffusion type still (MEDS) and the vacuum tube solar collector (VTSC). A MEDS prototype was designed and built. The measured result is very close to the estimation. The 10-effect MEDS will produce pure water at about 13.7 $\mathrm{L} /$ day $/ \mathrm{m}^{2}$ collector area at a solar irradiation of $600 \mathrm{~W} / \mathrm{m}^{2}$ and $19.7 \mathrm{~L} / \mathrm{day} / \mathrm{m}^{2}$ collector area at solar irradiation $800 \mathrm{~W} / \mathrm{m}^{2}$. For 20 -effect still, the yield rate increase is $32 \%$ compared to 10-effect still.
\end{abstract}

\section{KEYWORDS}

Solar desalination, Solar still, Multi-effect diffusion, Multi-effect diffusion solar still, Solar water purification, Solar distillation

\section{INTRODUCTION}

The multi-effect diffusion still (MEDS) is a high-efficiency heat-driven distillation device, which was published by Cooper and Appleyard in 1967 [1, 2]. Although some researchers developed MEDS for experiment [3-8], not many good application devices based on the principle of MEDS are available due to the problem of suitable manufacturing techniques. The present study intends to develop a high-performance solar-assisted desalination system (SADS) in which MEDS is adopted.

The MEDS (Figure 1) contains a number of vertical cells which are closely spaced. One face of each cell is a plain plate on which vapour condenses. A thin layer of capillary material (wick) is attached to the other side of this plate to act as a wick. Seawater is supplied to the wick at the top. The heating plate absorbs the heat released from the condensation of water vapour vaporized from the saturated wick of the upstream cell. The condensation heat is then conducted through the heating plate to heat the seawater inside the wick and produce vapour. The vapour diffuses towards and condenses at the next heating plate. The collectors under the heating plates collect the drops of pure water. Latent heat released during the condensation on the bare side of the heating plate evaporates the impure water which has saturated the wick material on the other side of the

* Corresponding author 
heating plate. The process repeats until the last cell and the residual heat is finally discharged to the environment.

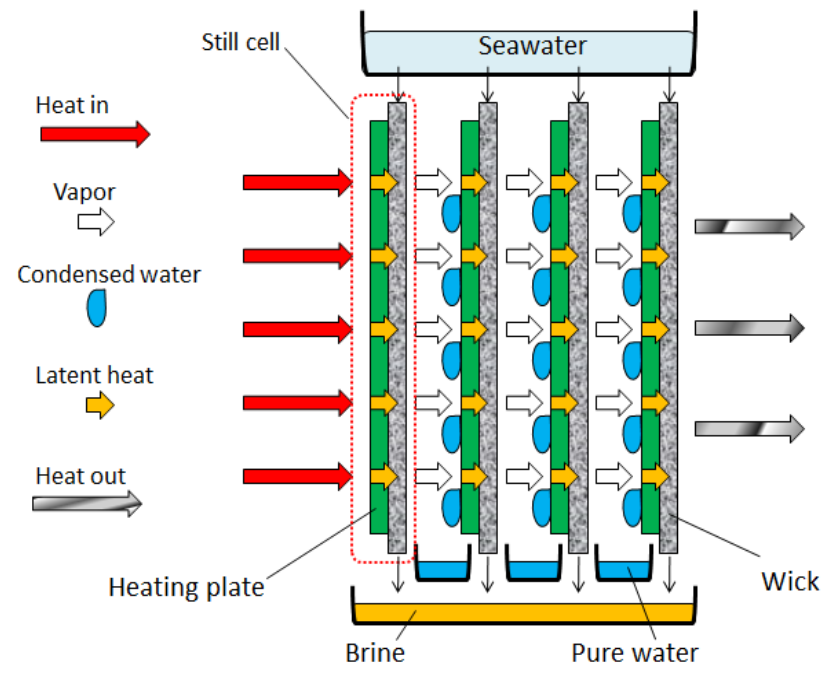

Figure 1. Multi-effect diffusion type still (MEDS)

The design principle of MEDS is perfect. But the vapour diffusion process in cells is difficult due to low convective heat and mass transfer and little vapour diffusion potential exists in each cell. The temperature gradient of each cell becomes smaller when more cells are used. There must be an optimal design on the total number of cells for the best performance. A lot of researches including innovative designs need to be done in order to make MEDS applicable.

For SADS (Figure 2), the vacuum-tube solar collector (VTSC) is used to supply heat. The solar heat absorbed by VTSC evaporates the water and produces high temperature steam as the heat source of MEDS. The vapour generated by solar heat condenses at the first heating plate of MEDS cell, releasing the latent heat in the distillation process. The hot salt brine product and hot pure water are used to preheat the input seawater. VTSC is designed using an automatic water feeding mechanism. When the VTSC is cooled down at night, by the function of check valves, it creates a negative pressure in the water storage which sucks the water into the storage spontaneously.

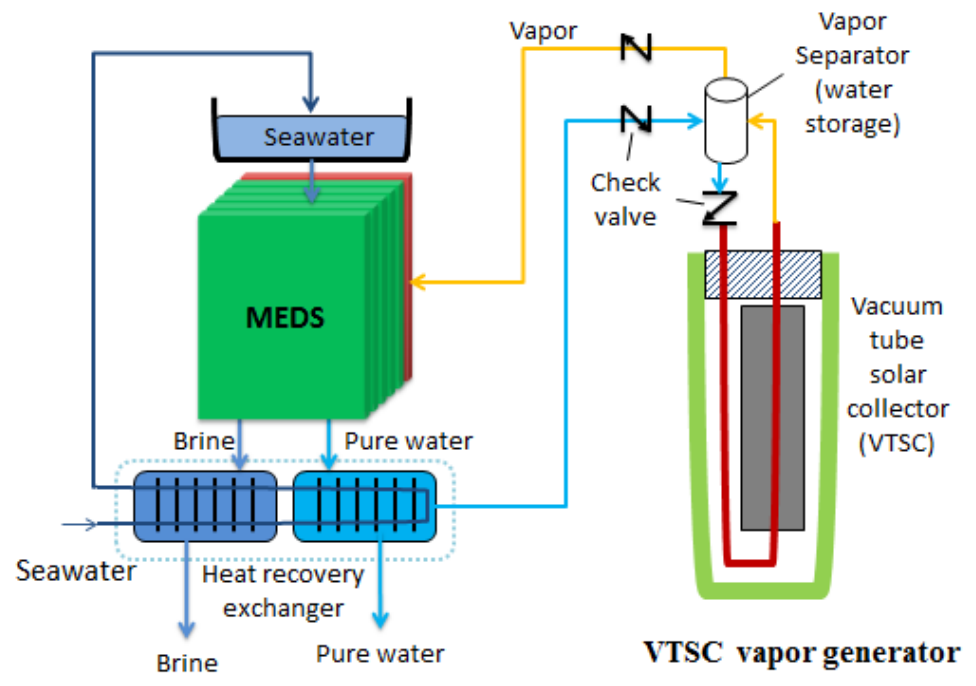

Figure 2. Solar-assisted desalination system (SADS) 


\section{DESIGN ANALYSIS OF MEDS}

For commercialization purpose, the design guidelines include low-cost, high efficiency, high reliability, and simple maintenance. The concept of modular design is employed. Especially for the components with short life time such as still cell, low-cost and replaceable design is necessary. The wicks of the still cells undergo degradation easily due to pollution by seawater. The design of cells should be in modular type for easy replacement.

The solar collector used for SADS is the module with 6 tubes of VTSC (Figure 3) and the total absorber area is $0.92 \mathrm{~m}^{2}$. The thermal efficiency of this VTSC module is about 0.5 at $100{ }^{\circ} \mathrm{C}$.

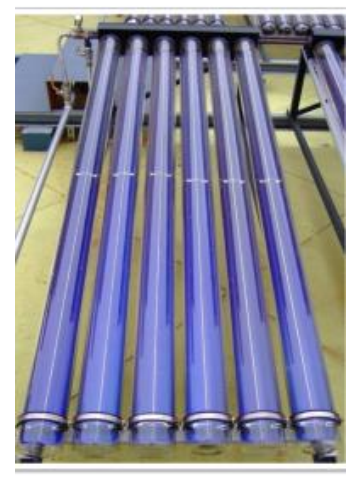

Figure 3. VTSC module

Table 1 shows the estimation of steam production rate at different levels of solar irradiation.

Table 1. Steam production estimation of VTSC module

\begin{tabular}{cccc}
\hline Solar irradiation, $\left[\mathrm{W} / \mathrm{m}^{2}\right]$ & 400 & 600 & 800 \\
\hline Vapour production rate, $[\mathrm{g} / \mathrm{min}]$ & 4.9 & 7.4 & 9.8 \\
\hline
\end{tabular}

The SADS is designed for seawater desalination. Since the concentration of salt in seawater is high, to avoid salt crystallization in the wick, there is a minimum seawater flow through the wick. The salt concentration of seawater is $0.036 \mathrm{~g} / \mathrm{ml}$, and the saturated salt solubility in water is 0.36 . From mass balance, we can derive the ratio of the production of pure water and that of salt brine. From the mass balance of total mass flow, we obtain:

$$
m_{i}=m_{v}+m_{e}
$$

where $m_{i}$ is the total mass flow rate at the inlet; $m_{v}$ is the mass flow rate of the evaporated vapour; $m_{e}$ is the mass flow rate at exit (brine). From the mass balance to the salt, we obtain

$$
C_{i} m_{i}=C_{e} m_{e} \text { or } m_{i}=C_{e} m_{e} / C_{i}
$$

where $C_{i}$ is the salt concentration at the inlet flow (0.036); $C_{e}$ is the salt concentration of exit (brine) (0.36). Combining Equations 1 and 2, we obtain the ratio of pure water vapour flow to the brine flow:

$$
r=\frac{m_{v}}{m_{e}}=\frac{C_{e}-C_{i}}{C_{i}}
$$


The theoretical analysis of heat and mass transfer of the MEDS is similar to [3-7] with a constraint that the ratio $r$ should be less than 9 in order to avoid salt crystallization in the wick.

A simple analysis was carried out in the present study. Within two adjoining still cells, the heat transfer from cell to cell is by three mechanisms: conduction, convection, and diffusion. Ignoring the heat leak from the edges of cell, the diffusion transfer will increase with decreasing gap between the cells. For the MEDS studied, the diffusion gap is small enough such that the diffusion process dominates the other transport processes, and the influence of conduction and convection can be ignored. That is, the heat transfer from cell to cell is dominated by water evaporation, diffusion, and vapour condensation and the major heat loss is from the overflow of salt brine. The simplified energy conservation equation for a single still cell then becomes:

$$
q_{i}=c_{p} \Delta T m_{i}+h_{f g} m_{v}
$$

where $q_{i}$ is the heat input, $h_{f g}$ is the latent heat of water, $c_{p}$ is the specific heat of water and $\Delta T$ is the temperature difference between input seawater and output salt brine. The mass flow rate of condensate, i.e. pure water production rate $\mathrm{m}_{v o}$, is equal to the mass flow rate of evaporation:

$$
\mathrm{m}_{v o}=m_{v}
$$

Combining Equations (3) to (5), we can estimate the pure water production rate for a single still cell from the following equation:

$$
\mathrm{m}_{v o}=\frac{q_{i}}{(r+1) c p^{\Delta T+h_{f g}}}
$$

The thermal resistances of each still cell, which are inversely proportional to the heat transfer area, cause the temperature gradient from cell to cell. To simplify the analysis, we assume that the temperature decreases uniformly from the heating plate of the first cell to the last. The total pure water production rate from all still cells can then be predicted. The total pure water yield per day (6 hours) for one module of VTSC (with solar thermal energy efficiency 0.5 ) can also be predicted for different values of solar irradiation.

A performance index is defined in the present study for performance evaluation. The solar energy coefficient of performance $\left(R_{S}\right)$ is defined as

$$
R_{S}=\frac{\text { total vapor condensation heat required for actual pure water production }}{\text { solar energy input to VTSC }}
$$

For the evaluation of the distillation process alone excluding the solar energy conversion efficiency, we define the distillation coefficient of performance $\left(R_{o}\right)$ as

$$
R_{O}=\frac{\text { total vapor condensation heat required for actual pure water production }}{\text { heat input to MEDS }}
$$

Table 2 shows some estimated results of 10-effect MEDS, and Table 3 for 20-effect MEDS, with $r=7$ and $T_{i}=30^{\circ} \mathrm{C}$. The daily average solar irradiation in Taiwan is about 
$600 \mathrm{~W} / \mathrm{m}^{2}\left(12.9 \mathrm{MJ} / \mathrm{m}^{2}\right.$ day) (in summer) and is about $800 \mathrm{~W} / \mathrm{m}^{2}\left(17.3 \mathrm{MJ} / \mathrm{m}^{2}\right.$ day) in desert area. If there is no heat recovery, for 10-effect MEDS, the daily pure water production rate (for 6 hours) is around $12.6 \mathrm{~L} /$ day/set $\left(13.7 \mathrm{~L} / \mathrm{m}^{2} /\right.$ day) in Taiwan and 18.1 $\mathrm{L} /$ day/set $\left(19.7 \mathrm{~L} / \mathrm{m}^{2} /\right.$ day) in desert area, where the solar absorber area of one set VTSC is $0.92 \mathrm{~m}^{2}$. This value is much higher than the stills we have ever made.

Table 2. Pure water production estimation of 10-effect MEDS

\begin{tabular}{cccccccccccccc}
\hline $\begin{array}{c}\text { Solar } \\
\begin{array}{c}\text { Irradiation, } \\
{\left[\mathrm{W} / \mathrm{m}^{2}\right]}\end{array}\end{array}$ & $1^{\text {st }}$ & $2^{\text {nd }}$ & $3^{\text {rd }}$ & $4^{\text {th }}$ & $5^{\text {th }}$ & $6^{\text {th }}$ & $7^{\text {th }}$ & $8^{\text {th }}$ & $9^{\text {th }}$ & $10^{\text {th }}$ & Total & $R_{S}$ \\
\hline 400 & 1.02 & 0.91 & 0.82 & 0.75 & 0.69 & 0.64 & 0.61 & 0.58 & 0.57 & 0.55 & 7.13 & 2.02 \\
600 & 1.8 & 1.6 & 1.44 & 1.32 & 1.22 & 1.14 & 1.08 & 1.03 & 1 & 0.98 & $\mathbf{1 2 . 6}$ & 2.37 \\
800 & 2.57 & 2.3 & 2.07 & 1.89 & 1.75 & 1.63 & 1.55 & 1.48 & 1.43 & 1.41 & $\mathbf{1 8 . 1}$ & 2.55 \\
\hline \multicolumn{10}{c}{10 10-eff } & Pure water yield, [L/day/set] with heat recovery & & \\
\hline 400 & 1.06 & 0.98 & 0.92 & 0.87 & 0.83 & 0.81 & 0.8 & 0.8 & 0.8 & 0.8 & 8.65 & 2.44 \\
600 & 1.86 & 1.73 & 1.62 & 1.54 & 1.48 & 1.43 & 1.41 & 1.41 & 1.41 & 1.41 & $\mathbf{1 5 . 3}$ & 2.88 \\
800 & 2.67 & 2.48 & 2.32 & 2.2 & 2.12 & 2.06 & 2.02 & 2.02 & 2.02 & 2.02 & $\mathbf{2 1 . 9}$ & 3.1 \\
\hline
\end{tabular}

For 20-effect MEDS, the daily pure water production rate (for 6 hours is around 16.5 $\mathrm{L} /$ day/set $\left(17.9 \mathrm{~L} / \mathrm{m}^{2} /\right.$ day $)$ in Taiwan and $23.7 \mathrm{~L} /$ day $/$ set $\left(25.8 \mathrm{~L} / \mathrm{m}^{2} /\right.$ day $)$ in desert area. For 20 -effect still, the yield rate increase is $32 \%$ compared to 10 -effect still. All the above results will be improved if the heat recovery device was added.

In reference [7], Tanaka proposed a MEDS coupled with heat-pipe solar collector. The daily water production of Tanaka's solar still with different number of effects was determined by theoretical analysis [7], Figure 7. For 10-effect still with solar radiation $24.4 \mathrm{MJ} / \mathrm{m}^{2}$ day, the daily water production of Tanaka's still is around $20 \mathrm{~L} / \mathrm{m}^{2}$ day. Assuming that the thermal efficiency of VTSC in present study is same as the solar collector of Tanaka's still, for similar weather condition and seawater feeding rate, the present theoretical prediction of daily water production in the 10-effect MEDS is 18 $\mathrm{L} / \mathrm{m}^{2}$ day, which differs by $10 \%$ compared with Tanaka's result.

Table 3. Pure water production estimation of 20-effect MEDS

\begin{tabular}{|c|c|c|c|c|c|c|c|c|c|c|c|c|}
\hline \multirow{2}{*}{$\begin{array}{c}\text { Solar } \\
\text { Irradiation }\end{array}$} & \multicolumn{11}{|c|}{ 20-eff Pure water yield [L/day/set] without heat recovery } & \multirow{2}{*}{$R_{S}$} \\
\hline & $2^{\text {nd }}$ & $4^{\text {th }}$ & $6^{\text {th }}$ & $8^{\text {th }}$ & $10^{\text {th }}$ & $12^{\text {th }}$ & $14^{\text {th }}$ & $16^{\text {th }}$ & $18^{\text {th }}$ & $20^{\text {th }}$ & Total & \\
\hline $400\left[\mathrm{~W} / \mathrm{m}^{2}\right]$ & 0.89 & 0.7 & 0.57 & 0.47 & 0.4 & 0.4 & 0.31 & 0.28 & 0.26 & 0.25 & 9.36 & 2.65 \\
\hline $600\left[\mathrm{~W} / \mathrm{m}^{2}\right]$ & 1.57 & 1.24 & 1 & 0.83 & 0.7 & 0.7 & 0.54 & 0.5 & 0.46 & 0.44 & 16.5 & 3.12 \\
\hline \multirow[t]{2}{*}{$800\left[\mathrm{~W} / \mathrm{m}^{2}\right]$} & 2.25 & 1.78 & 1.44 & 1.19 & 1.01 & 1.01 & 0.78 & 0.71 & 0.66 & 0.63 & 23.7 & 3.36 \\
\hline & \multicolumn{12}{|c|}{ 20-eff Pure water yield [L/day/set] with heat recovery } \\
\hline $400\left[\mathrm{~W} / \mathrm{m}^{2}\right]$ & 0.96 & 0.82 & 0.71 & 0.64 & 0.58 & 0.58 & 0.53 & 0.52 & 0.52 & 0.52 & 13 & 3.68 \\
\hline $600\left[\mathrm{~W} / \mathrm{m}^{2}\right]$ & 1.69 & 1.44 & 1.26 & 1.13 & 1.03 & 1.03 & 0.93 & 0.92 & 0.92 & 0.92 & 22.9 & 4.33 \\
\hline $800\left[\mathrm{~W} / \mathrm{m}^{2}\right]$ & 2.43 & 2.07 & 1.81 & 1.62 & 1.48 & 1.48 & 1.34 & 1.32 & 1.32 & 1.32 & 32.9 & 4.66 \\
\hline
\end{tabular}




\section{DESIGN OF MEDS}

Figure 4 shows the design of MEDS. All the components can be assembled and disassembled quickly. Twenty still cells can be installed in a unit of MEDS.

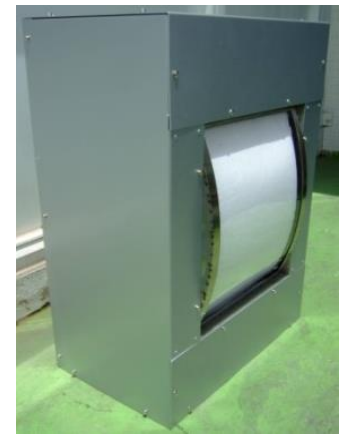

Figure 4. Design of MEDS

The vapour collector receives the vapour from vapour generator (e.g. solar collector). The wick is made of porous material which has high permeability and capillary effect.

The seawater supply contains a water distributor. The feeding rate can be controlled using different materials or adjusting the liquid level in the supply tank. The distributor can be replaced regularly.

The design of the heat recovery device is simply a water pipe covered by capillary material. The heat exchange occurs between the liquid in the capillary (input flow) and the liquid inside the pipe (pure hot water) to recover the heat.

The dimension of the still cell plate is $30 \mathrm{~cm} \times 40 \mathrm{~cm} \times 0.5 \mathrm{~mm}$, which is made of polycarbonate plastic. The separating distance between the adjacent still cells is $6 \mathrm{~mm}$. The still cells are handmade in lab for the experiment. Fabrication by moulding can be applied in mass production.

Figure 5 shows the external appearance of a MEDS unit. The dimension of the casing is $67 \mathrm{~cm} \times 28 \mathrm{~cm} \times 45 \mathrm{~cm}$. The pure water production capacity of one MEDS unit is to match with 3 tubes of VTSC at solar irradiation $600 \mathrm{~W} / \mathrm{m}^{2}$. For 1 set of VTSC, 1 to 3 units of MEDS are needed in different weather conditions.

Figure 3 shows the VTSC vapour generator used in the experiment, which is a flow-through type vacuum-tube collector. The vapour separator is added to the vacuum-tube collector as an accumulator and separator. The accumulator volume is 2.5 L.

\section{BASIC PERFORMANCE TEST OF MEDS}

The performance test of the MEDS prototype was carried out to understand the process of heating, evaporating, condensation, and flows at different parts. The vapour production rate of the VTSC has been tested at different solar irradiation levels. Table 4 shows that the measured results are very close to the estimated results. The uncertainty of the values is due to the unstable solar irradiation. The thermal performance test of VTSC vapour generator shows that the solar thermal conversion efficiency is about 0.6.

Table 4. VTSC vapour generator test

\begin{tabular}{ccc}
\hline $\begin{array}{c}\text { Solar irradiation, } \\
{\left[\mathrm{W} / \mathrm{m}^{2}\right]}\end{array}$ & $\begin{array}{c}\text { Measured, } \\
{[\mathrm{g} / \mathrm{h}]}\end{array}$ & $\begin{array}{c}\text { Estimated, } \\
{[\mathrm{g} / \mathrm{h}]}\end{array}$ \\
600 & $180-300$ & 294 \\
600 & $360-480$ & 444 \\
800 & $480-600$ & 588 \\
\hline
\end{tabular}


The MEDS distillation tests are carried out using an electric steam generator. Table 5 shows some test results. Test of the 10-effect MEDS without heat insulation and heat recovery shows that the heat leakage reduces $R_{o}$ by $20 \sim 30 \%$. The 20 -effect MEDS test with heat insulation and heat recovery shows that the measured $R_{o}$ is identical with the estimated result. The other conclusion from the test is that, a single unit of MEDS can produce pure water at $5 \mathrm{~L} /$ day (6 hours) at most.

Table 5. MEDS test using electric steam generator

\begin{tabular}{|c|c|c|c|c|}
\hline \multirow{2}{*}{$\begin{array}{c}\text { Vapour input, } \\
{[\mathrm{g} / \mathrm{h}]}\end{array}$} & \multicolumn{2}{|c|}{ Yield, [g/h] } & \multirow{2}{*}{$\begin{array}{c}\text { Measured } \\
\text { Ro } \\
\end{array}$} & \multirow{2}{*}{$\begin{array}{c}\text { Estimated } \\
\text { Ro }\end{array}$} \\
\hline & Pure water & Salt brine & & \\
\hline \multicolumn{5}{|c|}{ 10-effect (without heat insulation and heat recovery) } \\
\hline 234 & 1032 & 228 & 4.4 & 5.45 \\
\hline 276 & 972 & 744 & 3.5 & 4.35 \\
\hline 336 & 960 & 960 & 2.9 & 3.98 \\
\hline \multicolumn{5}{|c|}{ 20-effect (with heat insulation, without heat recovery) } \\
\hline 90 & 600 & 180 & 6.7 & 7.35 \\
\hline 84 & 546 & 240 & 6.5 & 6.74 \\
\hline 78 & 480 & 240 & 6.1 & 6.5 \\
\hline \multicolumn{5}{|c|}{ 20-effect (with heat insulation and heat recovery) } \\
\hline 102 & 738 & 624 & 7.2 & 7.2 \\
\hline 63 & 492 & 468 & 7.8 & 7.8 \\
\hline
\end{tabular}

The efficiency of the heat recovery device has been tested. Figure 6 shows that the input cold water is preheated and output hot water is cooled. The temperature difference between preheated water and cooled heat is about $8^{\circ} \mathrm{C}$. In other words, the effectiveness of the heat recovery device is greater than 0.9 .

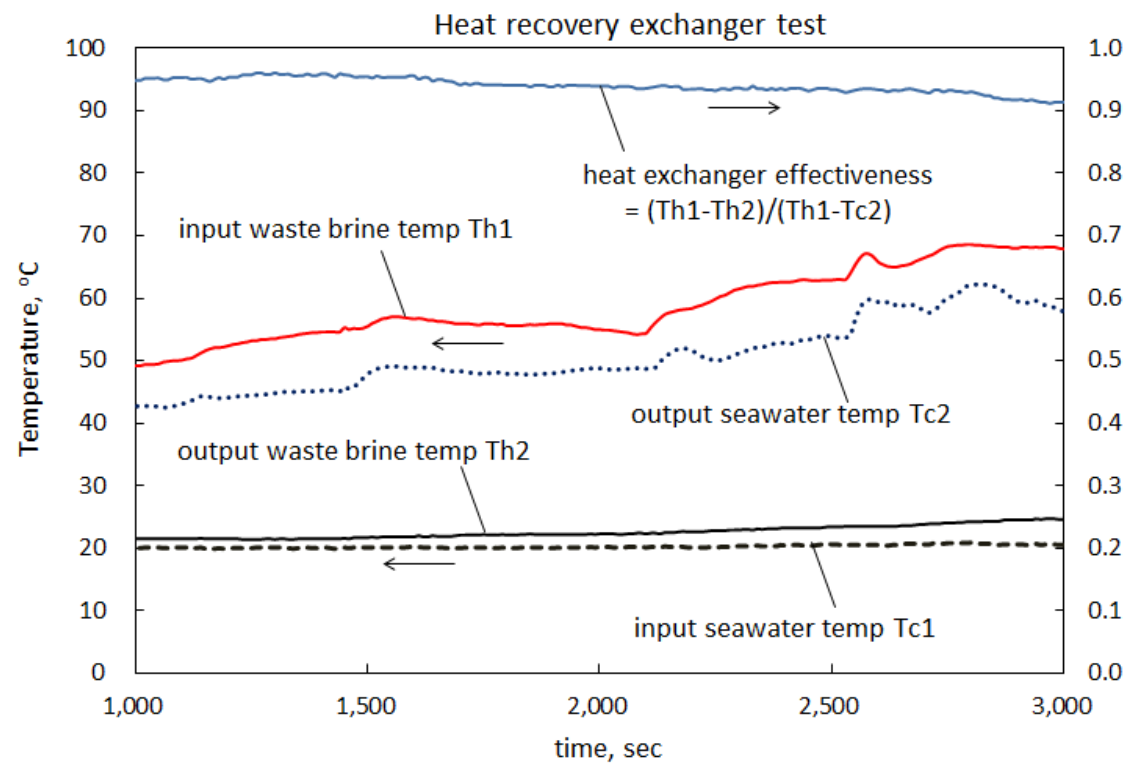

Figure 6. Heat recovery test

Since the spacing of still cell is very small $(<6 \mathrm{~mm})$, the condensed pure water flowing down the plate may be contaminated by the seawater across the small gap. We 
performed a test using dyed seawater in red colour as the input and observe the colour of the produced pure water. No contamination was found.

\section{OUTDOOR PERFORMANCE TEST OF SADS}

The prototype of SADS is completed by integrating MEDS with VTSC module (Figure 7). Some outdoor tests with different number of VTSC tubes were carried out.

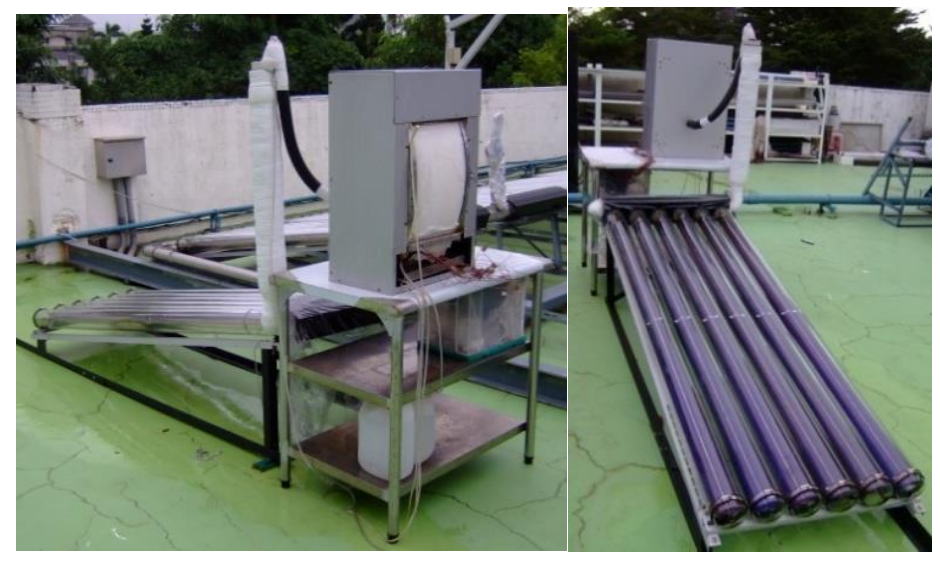

Figure 7. Outlook of SADS

Table 6 shows that at solar radiation $>900 \mathrm{~W} / \mathrm{m}^{2}$, one set of MEDS coupled with one tube of VTSC performs at the highest efficiency and the pure water production rate is $>18$ $\mathrm{L} / \mathrm{m}^{2} / 6 \mathrm{~h}$. This value is close to or even higher than the previous record for similar stills in the literature [8]. At lower solar radiation, more tubes of VTSC can be used to achieve high efficiency. The test has shown that the size of MEDS needs to be enlarged. The measured $R_{o}$ is good but $R_{S}$ does not compare to estimation. This indicates that there is a large energy loss for MEDS heat input from the vacuum-tube collector. The data analysis shows that the energy loss is 50-70\%, due to vapour leakage from the inlet vapour collector of MEDS. This means that the pure water production rate can increase about 3 fold, if the heat loss is controlled to $<20 \%$.

Table 6. SADS test with different number of VTSC tubes

\begin{tabular}{ccccc}
\hline $\begin{array}{c}\text { Number of VTSC } \\
\text { tubes }\end{array}$ & $\begin{array}{c}\text { Solar Irradiation, } \\
{\left[\mathrm{W} / \mathrm{m}^{2}\right]}\end{array}$ & $\begin{array}{c}\text { Production rate, } \\
{\left[\mathrm{L} / \mathrm{m}^{2} / 6 \mathrm{~h}\right]}\end{array}$ & $R_{o}$ & $R_{s}$ \\
\hline 3 & 600 & $\sim 10$ & $\sim 7$ & $\sim 1.5$ \\
2 & 900 & $\sim 15$ & $\sim 7$ & $\sim 1.7$ \\
1 & 900 & $>18$ & $\sim 8$ & $\sim 2$ \\
\hline
\end{tabular}

\section{DISCUSSION AND CONCLUSION}

The present study intends to develop high-performance solar-assisted desalination technology (SADS) using multiple-effect diffusion-type still (MEDS). The MEDS is designed using an innovative configuration. Performance analysis of MEDS was carried out. A MEDS prototype was built and tested with vacuum-tube solar collector. It shows that the measured result is very close to the estimation. Therefore, 10-effect MEDS will produce pure water at around $12.6 \mathrm{~L} /$ day/set $\left(13.7 \mathrm{~L} / \mathrm{m}^{2} /\right.$ day $)$ in Taiwan with solar 
irradiation $600 \mathrm{~W} / \mathrm{m}^{2}$ and $18.1 \mathrm{~L} /$ day/set $\left(19.7 \mathrm{~L} / \mathrm{m}^{2} /\right.$ day $)$ in desert area with solar irradiation $800 \mathrm{~W} / \mathrm{m}^{2}$.

For 20-effect MEDS, the daily pure water production rate (for $6 \mathrm{~h}$ ) is around 16.5 $\mathrm{L} /$ day/set $\left(17.9 \mathrm{~L} / \mathrm{m}^{2} /\right.$ day $)$ in Taiwan and $23.7 \mathrm{~L} /$ day $/$ set $\left(25.8 \mathrm{~L} / \mathrm{m}^{2} /\right.$ day $)$ in desert area. For 20-effect still, the yield rate increases by $32 \%$ compared to 10-effect still.

A design of SADS has been completed by integrating MEDS with VTSC module. At solar irradiation $900 \mathrm{~W} / \mathrm{m}^{2}$, one set of MEDS coupled with one tube of VTSC will perform at the highest efficiency, at pure water production rate $>18 \mathrm{~L} / \mathrm{m}^{2} / 6 \mathrm{~h}$. The test has shown that the size of MEDS needs to be enlarged, and there is a large input energy loss at MEDS for the heat supply from the vacuum tube collector. The energy loss is $50-70 \%$. The pure water production rate will increase about 3 fold, if the heat loss is controlled to be $20 \%$.

Further experiments on a full-scale MEDS prototype run with solar collector are needed. To achieve the above theoretical target, design modifications of the MEDS are required.

The heat and mass transfer through the small gap inside the still cell involves complicated transport phenomena. The thermal resistances from heating plate conduction, drop-wise condensation, and vapour diffusion process [9] need to be reduced by using various innovative designs. System design matching is also very important. Size matching between the vapour generator and the MEDS units needs more research.

How to keep a reasonable temperature gradient along the path of heat diffusion process is another key factor to achieve good results. Research on the optimum number of multi-effects is also needed.

The polycarbonate heating plate in the handmade unit is $0.5 \mathrm{~mm}$ thick. It can be reduced using moulding technique to reduce the conduction thermal resistance. The structural design of still cell can be further simplified for easy assembly and disassembly. Water makeup flow control is also very important in order to maintain good heat and mass transfer, since solar radiation is not steady. An optimal control may be needed.

\section{ACKNOWLEDGEMENT}

This publication is based on work supported by Award No.KUK-C1-014-12, made by King Abdullah University of Science and Technology (KAUST), Saudi Arabia.

\section{NOMENCLATURE}

$\begin{array}{ll}C_{e} & - \\ C_{i} & - \\ c_{p} & {\left[\mathrm{~kJ} \mathrm{~kg}^{-1} \mathrm{~K}^{-1}\right]} \\ h_{f g} & {\left[\mathrm{~kJ} \mathrm{~kg}^{-1}\right]} \\ m_{e} & {\left[\mathrm{~kg} \mathrm{~s}^{-1}\right]} \\ m_{i} & {\left[\mathrm{~kg} \mathrm{~s}^{-1}\right]} \\ m_{v} & {\left[\mathrm{~kg} \mathrm{~s}^{-1}\right]} \\ q_{i} & {[\mathrm{~W}]} \\ r & - \\ R_{s} & -\end{array}$

salt concentration at exit (brine) (0.36)

salt concentration at the inlet flow (0.036)

specific heat of water

latent heat of water

mass flow rate at exit (brine)

total mass flow rate at the inlet

mass flow rate of the evaporated vapour

heat input

ratio of pure water vapour flow to the brine flow

solar energy coefficient of performance (total vapour condensation heat required for actual pure water production over total solar energy input to VTSC), Eqn (7) 
$R_{o} \quad-\quad$ distillation coefficient of performance (total vapour condensation heat required for actual pure water production over total heat input to MEDS), Eqn (8) temperature difference between input seawater and output salt brine

\section{REFERENCES}

1. Kaushal, V. A., Solar stills: A review. Renewable and Sustainable Energy Reviews, 14, pp 446-453, 2010, http://dx.doi.org/10.1016/j.rser.2009.05.011

2. Cooper, P.I., Appleyard, J.A., The construction and performance of a three effect, wick-type, tilted solar still, Sun at Work, 12, pp 4-8, 1967

3. Bouchekima, B. Gros, B., Ouahes, R., Diboun, M., Performance study of the capillary film solar distiller, Desalination, 116, pp 185-192, 1998, http://dx.doi.org/10.1016/S0011-9164(98)00194-5

4. Tanaka, H., Nosoko, T., Nagata,T., A highly productive basin - type - multiple - effect coupled solar still, Desalination, 130, pp 279-293, 2000, http://dx.doi.org/10.1016/S0011-9164(00)00092-8

5. Tanaka, H., Nosoko, T., Nagata, T., Parametric investigation of a basin - type multiple - effect coupled solar still, Desalination, 130, pp 295-304, 2000, http://dx.doi.org/10.1016/S0011-9164(00)00093-X

6. Tanaka, H., Nosoko, T., Nagata,T., Experimental study of basin-type, multiple-effect, diffusion-coupled solar still, Desalination, 150, pp 131-144, 2002, http://dx.doi.org/10.1016/S0011-9164(02)00938-4

7. Tanaka, H., Nakatake, Y., A vertical multiple-effect diffusion-type solar still coupled with a heat-pipe solar collector, Desalination, 160, pp 195-205, 2004 , http://dx.doi.org/10.1016/S0011-9164(04)90009-4

8. Tanaka, H., Experimental study of vertical multiple-effect diffusion solar still coupled with a flat plate reflector, Desalination, 249, pp 34-40, 2009, http://dx.doi.org/10.1016/j.desal.2008.10.022

9. Rose, J.W., Dropwise condensation theory and experiment: a review, Proc Inst Mech Engrs Part A: J. Power and Energy, 216, pp 115-127, 2002, http://dx.doi.org/10.1243/09576500260049034 